\section{Lead and motor neurone disease}

The term "motor neurone disease" describes a progressive degenerative disorder of the central nervous system affecting the motor nuclei of the cranial nerves, the anterior horn cells of the spinal cord, and the descending corticospinal (pyramidal) tracts. This is the definition of the term as used in Britain, and when the initial brunt of the disease falls on the brain stem it usually produces progressive bulbar palsy, and when predominantly the spinal anterior horn cells are initially affected progressive muscular atrophy. The term "amyotrophic lateral sclerosis" is generally used when the early symptoms and signs are due to damage to the corticospinal tracts and when there is comparatively little evidence of lower motor neurone degeneration. In the United States, on the other hand, this term is often used (as is "motor system disease") as if it were synonymous with the British motor neurone disease.

Motor neurone disease is generally sporadic, rarely familial, and occurs worldwide and in all races. Symptoms usually develop between the ages of 50 and 70 years. The incidence is about 1 new case per 100000 population per year, with a prevalence of 2.5-7 per $100000 .^{12}$ The disease is, however, endemic in the Chamorro people on the island of Guam, where it shows a high familial incidence, often occurring in association with the so-called Parkinsonism-dementia complex. Nevertheless, it is still uncertain whether this form is genetically determined or whether it is due to a combination of genetic and environmental influences. ${ }^{3-6}$

Both the aetiology and pathogenesis of the condition remain obscure. While it may sometimes follow many years after an attack of acute anterior poliomyelitis ${ }^{7}$ or encephalitis lethargica, ${ }^{8}$ no concrete evidence favours viral infection, and attempts to isolate a causal virus from the spinal cords of patients have been unsuccessful. ${ }^{910} \mathrm{~A}$ link with malignant disease has been postulated, ${ }^{11}$ but recent work suggests that this is a chance association. ${ }^{12}$ Other unsubstantiated associations that have been suggested have been with diffuse angiopathy, ${ }^{13}{ }^{14}$ disorders of lipid and carbohydrate metabolism, ${ }^{15}{ }^{16}$ high concentrations of manganese and calcium in the central nervous system, ${ }^{17}$ and exocrine pancreatic dysfunction. There is some evidence ${ }^{18}$ of disordered protein metabolism in neurones (but not in myelin) and of abnormal DNA-directed mRNA synthesis in anterior horn cells, ${ }^{19}$ but whether these abnormalities indicate a fundamental pathogenetic mechanism is still uncertain. The postulate that the condition is due to premature aging in motor neurones, showing some indirect affinity with the process which occurs in cortical neurones in the presenile dementias, is commonly advanced but remains unsupported.

In 1970 Campbell and colleagues ${ }^{20}$ suggested that chronic lead intoxication might be an important factor, but this view was not widely accepted. Nevertheless, Conradi and colleagues ${ }^{21}$ found raised lead concentrations in the cerebrospinal fluid of patients when compared with controls, and more recently ${ }^{22}$ they have reported raised plasma lead concentrations in 16 patients compared with 18 control subjects. The plasma concentrations found, by the technique of flameless atomic absorption spectrophotometry, were lower in both the patients and the controls than those reported earlier for normal individuals; but nevertheless the concentrations in the patients were significantly higher than in the controls. They postulate that the exposure of the motor end plates to increased amounts of circulating lead in the plasma may result in the uptake of lead by the motor neurones and that this may be conducted by retrograde axoplasmic flow to the cell bodies-as occurs with various injected macromolecules (such as intravenous horseradish peroxidase). ${ }^{23}$

While many neurologists will think that it is inherently improbable that lead will prove to be the primary aetiological agent in motor neurone disease, the findings of this careful study cannot be ignored or dismissed lightly-especially when, in such a tragic progressive disease, we have no other clues to indicate an alternative, testable, working hypothesis.

${ }^{1}$ Kurland, L T, and Mulder, D W, Neurology (Minneapolis), 1954, 4, 355. Kurtzke, J F, in Motor Neuron Diseases, vol 2, eds F H Norris and L T Kurland, p 85. New York, Grune and Stratton, 1969.

${ }^{3}$ Kurland, L T, Proceedings of the Mayo Clinic, 1957, 32, 449.

4 Hirano, A, Kurland, L T, and Sayre, G P, Archives of Neurology (Chicago), 1967, 16, 232.

${ }^{5}$ Kurland, L T, Federation Proceedings, 1972, 31, 1540.

${ }^{6}$ Reed, D M, Brody, J A, and Holden, E M, Neurology (Minneapolis), 1975 , 25, 277.

${ }^{7}$ Hallen, O, Brusis, T, and Pfisterer, H, Deutsche Zeitschrift Nervenheilkunde, $1969,195,333$

${ }^{8}$ Milhorat, A T, Archives of Neurology and Psychiatry (Chicago), 1946, 55, 134

${ }^{9}$ Cremer, N E, et al, Archives of Neurology (Chicago), 1973, 29, 331.

${ }^{10}$ Liversedge, L A, and Campbell, M J, in Disorders of Voluntary Muscle, 3rd edn, ed J N Walton, p 775. Edinburgh and London, Churchill Livingstone, 1974.

${ }^{11}$ Brain, Lord, Croft, P B, and Wilkinson, M, Brain, 1965, 88, 479.

12 Jokelainen, M, Fournal of the Neurological Sciences, 1976, 29, 55.

13 Störtebecker, P, et al, Neurology (Minneapolis), 1970, 20, 1157.

14 Urbánek, K, and Jansa, P, Archives of Neurology (Chicago), 1974, 30, 186.

15 Ionasescu, V, and Luca, N, Acta Neurologica Scandinavica, 1964, 40, 47.

16 Gustafson, A, and Störtebecker, P, Neurology (Minneapolis), 1972, 22, 528.

17 Yase, Y, Lancet, 1972, 2, 292

18 Savolainen, H, and Palo, J, Brain, 1973, 96, 537.

${ }_{10}$ Mann, D M A, and Yates, P O, Fournal of Neurology, Neurosurgery and Psychiatry, 1974, 37, 1036.

20 Campbell, A M G, Williams, E R, and Barltrop, D, fournal of Neurology, Neurosurgery and Psychiatry, 1970, 33, 877.

${ }^{21}$ Conradi, S, Ronnevi, L-O, and Vesterberg, O, Fournal of the Neurological Sciences, 1976, 29, 259.

22 Conradi, S, Ronnevi, L-O, and Vesterberg, O, fournal of Neurology, Neurosurgery and Psychiatry, 1978, 41, 389.

${ }^{23}$ Broadwell, R D, and Brightman, M W, fournal of Comparative Neurology, 1976, 166, 257.

\section{Health visitors of the future}

Most doctors, and other health professionals too, have only a vague picture of the work and skills of health visitors. The success of attachments to general practice has undoubtedly improved relations and led to better mutual understanding, but there are still many family doctors and health visitors who see little of one another despite their professed responsibility for the health of the same people. Health visitors are, however, aware of these uncertainties, and their determination to reduce them is shown by the contents of a booklet ${ }^{1}$ published by their statutory supervising body, the Council for the Education and Training of Health Visitors. The council decided four years ago that if health visiting was to progress "the profession must spell out its implicit principles which ultimately predict and guide its practice." Any profession which attempts a statement of the principles on which its practice is based finds it a daunting taskyet without pointers to the future how can health visitors (or doctors for that matter) be confident about their ability to cope with a world in which change is constant and normal ? ${ }^{2}$

A working group composed mainly of health visitor tutors began by defining the professional practice of health visiting as "planned activities aimed at the promotion of health and prevention of ill-health"-for health visitors are primarily concerned with helping people to make the most of their health. The borderlines between health and sickness have, says the report, become blurred. Obesity, alcoholism, depression, bereavement, sexual deviations, and strained family relationships are seen nowadays as diseases rather than problems for the individual; moreover, many health problems are induced by the way of life chosen by individuals. The working party argued that health is a value and that health visitors should help people to search for their health needs and meet them. This search must, however, be purposeful and well informed, and health visitors can give explicit help-if they are trained "in logical, critical thinking and in scientific method." 